University of Montana

ScholarWorks at University of Montana

Ecosystem and Conservation Sciences Faculty

Publications

Ecosystem and Conservation Sciences

2003

\title{
Soil Microbial Dynamics and Biogeochemistry in Tropical Forests and Pastures, Southwestern Costa Rica
}

Cory C. Cleveland

The University of Montana, cory.cleveland@umontana.edu

Alan R. Townsend

Steven K. Schmidt

Briana C. Constance

Follow this and additional works at: https://scholarworks.umt.edu/decs_pubs

Part of the Ecology and Evolutionary Biology Commons

Let us know how access to this document benefits you.

\section{Recommended Citation}

Cleveland, Cory C.; Townsend, Alan R.; Schmidt, Steven K.; and Constance, Briana C., "Soil Microbial Dynamics and Biogeochemistry in Tropical Forests and Pastures, Southwestern Costa Rica" (2003). Ecosystem and Conservation Sciences Faculty Publications. 17.

https://scholarworks.umt.edu/decs_pubs/17

This Article is brought to you for free and open access by the Ecosystem and Conservation Sciences at ScholarWorks at University of Montana. It has been accepted for inclusion in Ecosystem and Conservation Sciences Faculty Publications by an authorized administrator of ScholarWorks at University of Montana. For more information, please contact scholarworks@mso.umt.edu. 


\title{
SOIL MICROBIAL DYNAMICS AND BIOGEOCHEMISTRY IN TROPICAL FORESTS AND PASTURES, SOUTHWESTERN COSTA RICA
}

\author{
Cory C. Cleveland, ${ }^{1,2,3}$ Alan R. Townsend, ${ }^{1,2}$ Steven K. Schmidt, ${ }^{2}$ and Briana C. Constance ${ }^{1}$ \\ ${ }^{1}$ Institute of Arctic and Alpine Research (INSTAAR), University of Colorado, Campus Box 450, Boulder, \\ Colorado 80309 USA \\ ${ }^{2}$ Department of Environmental, Population and Organismic Biology, Campus Box 334, University of Colorado, Boulder, \\ Colorado 80309 USA
}

\begin{abstract}
Tropical rain forest ecosystems are currently undergoing unprecedented rates of land conversion and land use change. Recent research suggests these activities profoundly influence nutrient cycling, but the principal mechanisms driving variation in nutrient status following land conversion are still not well understood. In this study, we used soils of varying fertility (oxisols and mollisols) in Costa Rica to investigate how conversion of tropical rain forest to cattle pasture affects the size and function of the microbial community, and to explore possible relationships between microbial dynamics and biogeochemistry.

Our pasture sites are relatively lightly managed, and total pools of carbon (C), nitrogen $(\mathrm{N})$, and phosphorus (P) were not significantly different from their forest counterparts. However, pools of available elements were different; most notably, plant available forms of $\mathrm{P}$ were significantly lower in the oxisol pasture than in the oxisol forest site. In addition, we found that land conversion led to fundamental changes in the size and activity of the soil microbial community. Microbial biomass was consistently higher in forests than in pastures, particularly in the oxisol sites, where it was more than twice the pasture value. Forest sites were also characterized by a microbial community that was more active, responded more rapidly to carbon substrate additions, and showed strong seasonal variation. Our results provide evidence that changes in biogeochemical cycling following land conversion observed here and elsewhere may be directly related to changes in microbial community structure and function.
\end{abstract}

Key words: carbon; land use change; mollisols; nitrogen; nutrient limitation; Osa Peninsula, Costa Rica; oxisols; phosphorus; soil microorganisms; tropical rain forest.

\section{INTRODUCTION}

On a global basis, deforestation and subsequent land use in tropical ecosystems removes roughly $2 \%$ of the remaining forest cover per year (Williams and Chartres 1991, Houghton 1994, Nepstad et al. 1999). The majority of cleared tropical forests are converted to cattle pasture (Fearnside 1996), a change that can have profound effects on biogeochemical and biophysical processes. For example, forest-to-pasture conversion can lead to (1) declines in total soil organic matter (SOM) and plant productivity, (2) increased emissions of radiative and chemically active trace gases, (3) substantial changes in the hydrologic cycle, and (4) elevated losses of important limiting elements through leaching (Uhl and Jordan 1984, Buschbacher et al. 1988, Cerri et al. 1991, Nepstad et al. 1991, Matson et al. 1997, Neill et al. 1997, Townsend et al. 2002).

The environmental consequences of land conversion in tropical ecosystems are potentially quite serious at multiple scales, and thus have been the focus of numerous recent studies. A growing body of evidence now suggests that land conversion can lead to funda-

Manuscript received 29 April 2002; revised 22 July 2002; accepted 22 July 2002. Corresponding Editor: D. S. Schimel.

${ }^{3}$ E-mail: cory.cleveland@colorado.edu mental changes in carbon (C) and nutrient cycling, but that the nature and extent of such changes vary widely across gradients in climate, soil type, and management strategies (Sanchez et al. 1983, Werner et al. 1984, Buschbacher et al. 1988, Spaans et al. 1989, de Moraes et al. 1996, Groffman et al. 2001). For example, strong declines in soil carbon pools and in nitrogen availability have been reported for a variety of pasture chronosequences (Buschbacher et al. 1988, Tiessen et al. 1992, Veldkamp et al. 1994, Davidson et al. 1995), but such declines are not ubiquitous for all managed pastures (Neill et al. 1997). As well, recent evidence showed that tropical land conversion could lead to substantial decreases in available phosphorus (P), the probable limiting element in many lowland tropical ecosystems (Tiessen et al. 1992, Asner et al. 1999, Townsend et al. 2002). However, the patterns in P cycling following deforestation varied with climate, soil type, and management strategy (Garcia-Montiel et al. 2000, Townsend et al. 2002). Thus, while the biogeochemical patterns following land conversion are becoming well documented, and the potential for losses of soil organic matter and key nutrients has been clearly established (Werner 1984, Buschbacher et al. 1988, Eden et al. 1991, Townsend et al. 2002), the principal mechanisms 


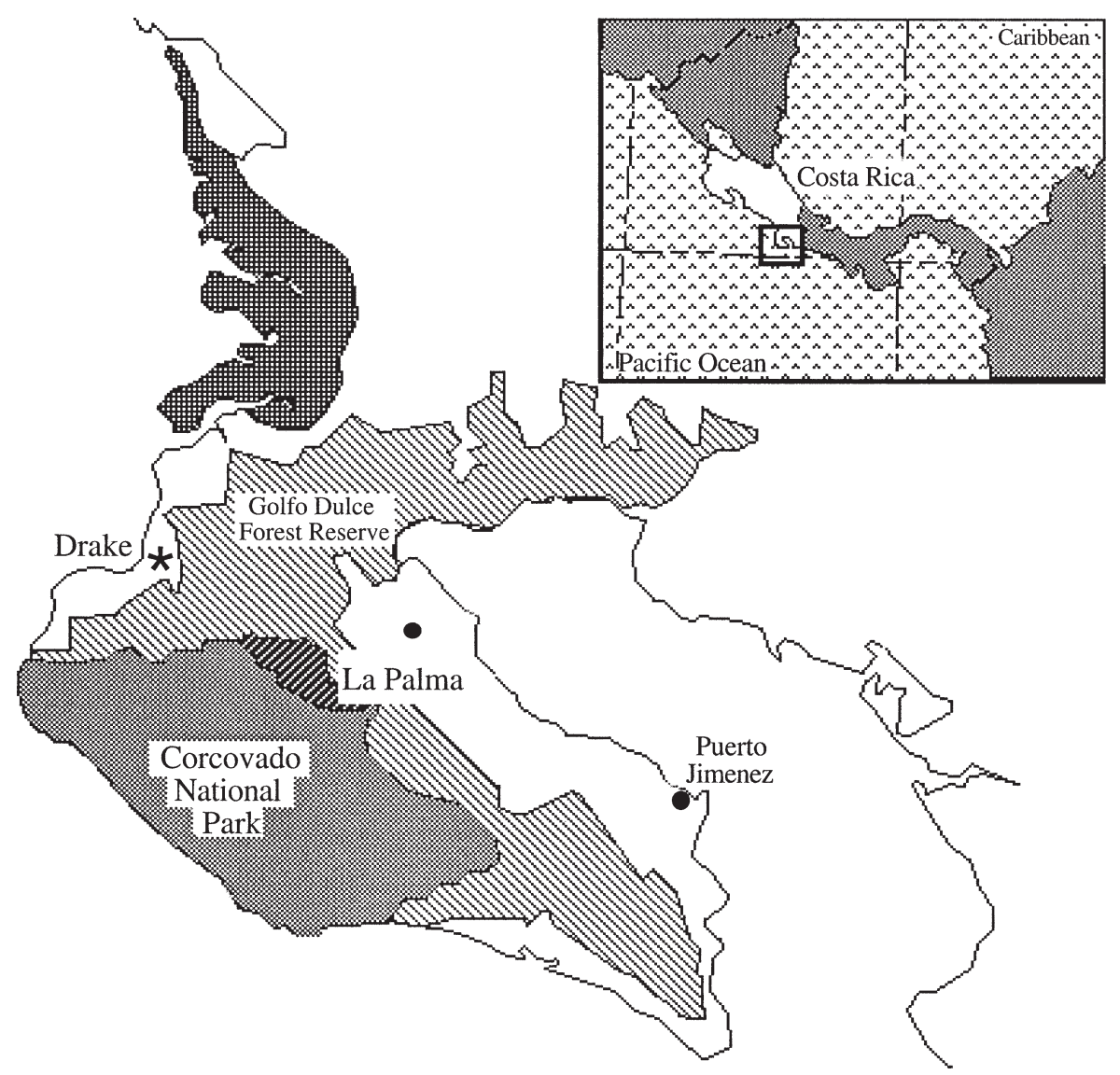

FIG. 1. Map of the Osa Peninsula in southwestern Costa Rica, indicating the study area (Drake).

driving the variation in and extent of such changes are still not well understood.

To date, most work has focused on either abiotic or plant-driven controls over biogeochemical changes following land conversion. However, a largely ignored possibility is that land transformation disrupts the structure and activity of the soil microbial community, which in turn affects the measured biogeochemical variables. The decomposition of soil organic matter and the mineralization of nutrients are mediated by microorganisms, and the significant environmental changes associated with land conversion are quite likely to alter the structure of such communities (Bornemann and Triplett 1997, Nüsslein and Tiedje 1999). While the links between microbial community structure and key biogeochemical functions are still poorly understood, it seems probable that significant disturbances to such communities may in turn cause important shifts in biogeochemical cycling. Thus, an understanding of the way microbial processes regulate biogeochemical cycles along axes of disturbance may be essential to understanding biogeochemical patterns following land conversion and land use change in tropical ecosystems.

In this study, we used soils of varying fertility (oxisols and mollisols) spanning both primary forest and pasture to investigate changes in the size and function of the microbial community following land conversion. Previous work by our group (Townsend et al. 2002) showed significant biogeochemical changes, especially in phosphorus cycling, between forests and pastures on both soil types. Here, we explore the possibility that land use-driven disturbances to the soil microbial community may help explain these patterns.

\section{Materials and Methods \\ Study site and sample collection}

The study area was near the town of Drake on the Osa Peninsula in southwestern Costa Rica (Fig. 1). This region lies within the tropical wet lowland forest bioclimate (Holdridge et al. 1971). Rainfall is heavy ( $>5000 \mathrm{~mm} / \mathrm{yr}$ ) and peaks during summer to early fall (June-October). Like most tropical rainforests, those on the Osa Peninsula still experience a dry season; in this region, it occurs from January to March. These dry seasons are quite short in comparison to many other tropical forests, and overall rainfall is very high, thus, nearly all forms of vegetation persist in an evergreen state throughout the year.

The entire Osa Peninsula was formed in three large seafloor volcanic events between $\sim 75$ and 40 million 
years ago, but some parts of the region were below sea level in more recent geologic eras (Berrange and Thorpe 1988). This created a wide range in the ages of parent materials and subsequent soil types, from highly weathered oxisols $\geq 40$ million years old to highly fertile alluvial mollisols of Quaternary origin. Thus, forests in this region occur on three general soil types: (1) old, highly weathered oxisols on steeply dissected terrain that rarely exceeds a few hundred meters in elevation, (2) much younger ultisols (2-4 million years old) on roughly similar upland terrain, and (3) the highly fertile mollisols found on the alluvial plains. Our sites are located in the northwest corner of the Drake River Valley $\left(8^{\circ} 43^{\prime} \mathrm{N}, 83^{\circ} 37^{\prime} \mathrm{W}\right)$, near the transition between the old upland oxisols and the younger lowland mollisols. We selected two forest and two pasture (20 yr old) sites representing each soil type, hereafter referred to as Oxisol Forest (OF), Oxisol Pasture (OP), Mollisol Forest (MF), and Mollisol Pasture (MP) sites. All four sites are only a few hundred meters apart, and are thus identical climatically (mean average temperature is $26^{\circ} \mathrm{C}$, mean average precipitation is $\sim 5100$ $\mathrm{mm} / \mathrm{yr}$ ). The pasture sites were dominated by the introduced $\mathrm{C}_{4}$ grass Panicum maximum, while the forests were characterized by high diversity, with no dominant single species. All pastures were originally cleared using slash-and-burn methods, but have not been burned since the initial clearing; woody encroachment is controlled via cutting and herbicides.

We sampled soils from all sites during February and June 2000 . At each site, eight $6 \times 10 \mathrm{~cm}$ soil samples were extracted every $5 \mathrm{~m}$ from two randomly placed 25-m transects bisecting each site, for a total of 10 samples per site. Soils were sampled to $10 \mathrm{~cm}$, reflecting the region of greatest microbial density and activity commonly observed in the soil profile (Ekelund et al. 2001). The soils at all sites lacked a distinct organic layer, and samples from $0-10 \mathrm{~cm}$ were texturally similar to deeper mineral soil (Townsend et al. 2002). Within $72 \mathrm{~h}$ of collection, soils were returned to the laboratory and coarsely sieved $(4 \mathrm{~mm})$ to remove plant material. A portion of each sample was then removed and air dried for chemical analysis. Fresh soil samples for microbial analyses were stored at $10^{\circ} \mathrm{C}$, and all experiments were initiated within $96 \mathrm{~h}$ of soil sampling to minimize artifacts incurred during long-term storage.

\section{Soil biogeochemical characteristics}

We measured $\mathrm{pH}$ on air-dried soils using a soil:deionized water paste $(1: 1)$. Soils to be tested for organic $\mathrm{C}$ and $\mathrm{N}$ were ground to pass a screen of $0.5 \mathrm{~mm}$ and analyzed using a Carlo Erba EA 1110 elemental analyzer (CE Elantech, Incorporated, Lakewood, New Jersey, USA). Extractable $\mathrm{N}\left(\mathrm{NH}_{4}{ }^{+} / \mathrm{NO}_{3}{ }^{-}\right)$was determined using a $2 \mathrm{~mol} / \mathrm{L} \mathrm{KCl}$ solution, extracted for $24 \mathrm{~h}$ and analyzed for $\mathrm{NH}_{4}{ }^{+}$and $\mathrm{NO}_{3}{ }^{-}$colorometrically on an Alpkem autoanalyzer (OI Analytical, College Station,
Texas, USA). Soil bulk density was determined using an excavation method (Parent and Caron 1993).

\section{$P$ fraction analyses}

One gram of soil from each sample was analyzed for $P$ fractions using the first two steps of the modified Hedley fractionation described by Tiessen and Moir (1993). Briefly, soil was subjected to a resin extraction (in water), followed by a bicarbonate extraction. A persulfate digest was also performed after the bicarbonate extraction, and organic $\mathrm{P}$ was determined by difference. These two fractions (resin and bicarbonate) are the most labile forms of $\mathrm{P}$, and their sum is often taken as a proxy for readily available (labile) $\mathrm{P}$; previous studies have shown that bicarbonate-extractable $\mathrm{P}$ is well correlated with plant growth (Bowman et al. 1978, Levy and Schlesinger 1999). Total P in soil samples was determined by digesting $5 \mathrm{~g}$ of sieved, air-dried soil in $\mathrm{H}_{2} \mathrm{SO}_{4}$ and $\mathrm{H}_{2} \mathrm{O}_{2}$. Phosphate concentrations in all measured fractions were determined using the ammonium molybdate-ascorbic acid method (Kuo 1996).

\section{Microbial biomass $C$ and $N$}

Microbial biomass $\mathrm{C}$ and $\mathrm{N}$ were determined using the chloroform fumigation-extraction method (Brookes et al. 1985). Fumigated (5 d) and unfumigated samples (10 g dry mass) were extracted with $0.5 \mathrm{~mol} / \mathrm{L} \mathrm{K}_{2} \mathrm{SO}_{4}$, centrifuged for $5 \mathrm{~min}$ at $5400 \mathrm{rev} / \mathrm{min}$ and filtered through ashed 1.0- $\mu \mathrm{m}$ Gelman GF/F glass fiber filters. Organic $\mathrm{C}$ in the extracts was analyzed using a Shimadzu TOC-5050A total organic carbon analyzer (Shimadzu Corporation, Kyoto, Japan). Microbial biomass $\mathrm{C}$ was determined as the difference between extractable $\mathrm{C}$ in fumigated and unfumigated samples using proportionality constant $(\mathrm{Kc})$ of 0.45 (Vance et al. 1987). Filtered extracts were also analyzed for $\mathrm{NH}_{4}{ }^{+}$and $\mathrm{NO}_{3}{ }^{-}$ colorimetrically using an Alpkem autoanalyzer. Total $\mathrm{N}$ in soil extracts was determined following digestion with potassium persulfate (D'Elia et al. 1977). Microbial biomass $\mathrm{N}$ was determined as the difference between extractable $\mathrm{N}$ in fumigated and unfumigated samples using a correction factor $(\mathrm{K} n)$ of 0.54 (Brookes et al. 1985).

\section{Microbial activity and active biomass}

Phosphatase activity.-Potential phosphatase activity was measured using a method in which enzyme activity releases p-nitrophenol (pNP) from added substrates, and levels of pNP are determined colorimetrically (Tabatabai and Bremner 1969). Briefly, 2-3 g of soil (dry mass) was combined with $150 \mathrm{ml}$ of acetate buffer at $\mathrm{pH}$ 5. The pNP-phosphatase substrate was added to the slurry and incubated at $25^{\circ} \mathrm{C}$ for $2 \mathrm{~h}$. Individual samples were centrifuged, and the supernatant mixed with $\mathrm{NaOH}$ to halt enzyme activity and cause coloration of the samples. Levels of pNP were measured at 410-nm absorbance using an Agilent 8453 benchtop spectrophotometer (Agilent Technologies, 
Palo Alto, California, USA). Although this method is not sensitive enough to separate abiotic, extracellularly, or intracellularly released enzymes, for enzyme activity to be detected using this assay, enzymes must cleave substrates that are too large to pass through cell membranes. Therefore, this assay effectively measures activity occurring outside of microbial cells and plant roots (Olander and Vitousek 2000).

Microbial activity.-We also assessed microbial activity and active microbial biomass using the substrateinduced growth response (SIGR) method described by Colores et al. (1996). Briefly, 10-15 g dry mass equivalent of each soil was placed in a biometer flask and brought to $50 \%$ water holding capacity (WHC) with deionized water. Amounts of carbon substrate previously determined to induce maximal respiration (sensu Colores et al. 1996) were added to each flask with the same uniformly labeled ${ }^{14} \mathrm{C}$ substrate to yield $2500 \mathrm{~Bq}$ (150000 dpm) per flask, and $1 \mathrm{ml} \mathrm{NaOH}$ in the sidearm to trap evolved $\mathrm{CO}_{2}$ (Colores et al. 1996). The base trap was removed from each flask and refreshed at regular intervals. Radioactivity was measured by liquid scintillation counting after mixing with Scintiverse II scintillation cocktail (Fisher Scientific, Pittsburgh, Pennsylvania, USA) to determine respiration rate. Flasks were incubated at $22^{\circ} \mathrm{C}$ until soil respiration returned to its basal rate $(\sim 56 \mathrm{~h})$. Respiration data were analyzed with Kaleidagraph software (Synergy Software 2000) using equations derived by Colores et al. (1996). To convert units of SIGR biomass ( $\mu \mathrm{g} \mathrm{CO}_{2}-\mathrm{C} /$ $\mathrm{g}$ soil sample) to $\mathrm{mg} \mathrm{C}$ biomass/g, empirically derived yields $\left(Y_{c}\right)$ of 0.50 for glutamic acid and 0.11 for salycilate were used in the equation $X_{\mathrm{a}}=X_{1}\left(Y_{\mathrm{c}} / 1-Y_{\mathrm{c}}\right)$, where $X_{\mathrm{a}}$ is the actual biomass in $\mathrm{mg} \mathrm{C}$ biomass $/ \mathrm{g}$, and $X_{1}$ is the biomass in units of $\mathrm{mg} \mathrm{CO}_{2}-\mathrm{C} / \mathrm{g}$ (Colores et al. 1996, Lipson et al. 1999). Substrate-induced respiration (SIR) estimates represent the initial respiration rates measured $2-3 \mathrm{~h}$ after substrate additions.

Microbial response to $C$ and $P$ amendments.- Responses of microbial respiration following the addition of different $\mathrm{C}$ compounds with and without the addition of $\mathrm{P}$ were also determined using radiolabeled substrates. In this study, we used two carbon substrates that varied in quality, and thus targeted two individual functional groups. First, we used the amino acid glutamate to determine the physiological response of the community to an N-rich, extremely labile C substrate. Like glucose, glutamate may be mineralized by a large percentage of the soil microbial community (Lipson et al. 1999). However, glutamate elicits higher microbial responses than other simple sugar compounds such as glucose (glucose additions do not always elicit consistent responses in the SIGR assay, even when added with a full suite of nutrients), and glutamate has a carbon:nitrogen ratio $(5: 1)$ that is sufficient to promote microbial growth (Lipson et al. 1999).

Next, we targeted a more specific functional group by adding radiolabeled salicylate (Sal). Salicylate is mineralized by the same general pathways as breakdown products from lignin and detrital polyphenols (Ley et al. 2001), and does not contain N, thereby allowing us to assess the effects of adding $\mathrm{P}$ alone, without the possible confounding effects of $\mathrm{N}$ in the carbon substrate. We thus used glutamate $(2 \mathrm{mg}$ glutamate$\mathrm{C} / \mathrm{g}$ ) in the assay to measure the response of the microbial population responsive to labile $\mathrm{C}$ substrates, and salicylate $(0.1 \mathrm{mg} \mathrm{Sal}-\mathrm{C} / \mathrm{g})$ to measure the response of a more specialized functional group that may utilize more recalcitrant plant detritus and humic materials as carbon and energy sources.

Phosphorus constraints on the soil microbial community have been previously demonstrated in tropical soil, and $\mathrm{P}$ availability may regulate the response of the microbial community to $\mathrm{C}$ inputs (Cleveland et al. 2002). Thus, in combination with our C-substrate addition experiments, we also tested the effects of adding labile, inorganic $\mathrm{P}$ on the response of the microbial community to our $\mathrm{C}$-substrate additions in the substrate addition incubations. For the fertilizer treatments, $\mathrm{P}$ was added as $\mathrm{KH}_{2} \mathrm{PO}_{4}$ to water amendments to yield $\mathrm{P}$ additions of $200 \mu \mathrm{g} / \mathrm{g}$.

\section{Statistical analyses}

Differences between sites on the same soil type were tested with $t$ tests for independent samples (SPSS 2000). In time-course incubations, fluxes were logtransformed before ANOVA. Differences in microbial growth rates following substrate addition between sites were determined with linear regression following log transformation of rate data during the exponential growth phase. Comparisons of different regression lines to estimate homogeneity between growth rates were done according to the methods described in Steel and Torrie (1960). All results are reported as significant when $P<0.05$.

\section{RESUlts}

\section{Soil characteristics}

Soil biogeochemical patterns in the oxisol forest and the oxisol pasture are shown in Table 1. Percentage of soil $\mathrm{C}$ and $\mathrm{N}$ were significantly higher in the forest than in the pasture sites, but the higher bulk densities of the pasture soils result in no significant differences in total soil $\mathrm{C}$ and $\mathrm{N}$ stocks (Table 1). Soil extractable inorganic $\mathrm{N}$ at $\mathrm{OP}$ was less than half the value observed at $\mathrm{OF}$, with the forest site showing higher values for both extractable $\mathrm{NO}_{3}-\mathrm{N}$ and $\mathrm{NH}_{4}-\mathrm{N}$.

At the mollisol sites, soil $\mathrm{C}$ and $\mathrm{N}$ stocks were not significantly different. However, while total extractable $\mathrm{N}$ was not significantly different at MF and MP, the patterns in $\mathrm{NH}_{4}{ }^{+}$and $\mathrm{NO}_{3}{ }^{-}$were strikingly different; $97 \%$ of the extractable $\mathrm{N}$ at MP was $\mathrm{NH}_{4}-\mathrm{N}$ vs. $59 \%$ in the MF forest. Perhaps somewhat surprisingly, soil $\mathrm{pH}$ values decreased from the forest to the pasture sites on both soil types (Table 1). 
TABLE 1. Soil biogeochemical characteristics $(0-10 \mathrm{~cm})$ of forest and pasture soils on oxisol and mollisol soils at the study site in tropical wet lowland forest in southwest Costa Rica.

\begin{tabular}{|c|c|c|c|c|}
\hline \multirow[b]{2}{*}{ Parameter } & \multicolumn{4}{|c|}{ Site } \\
\hline & OF & OP & MF & MP \\
\hline $\begin{array}{l}\mathrm{pH} \\
\text { Soil C (\%) } \\
\text { Soil C (\% change) } \\
\text { Soil N (\%) }\end{array}$ & $\begin{array}{l}5.4 \pm 0.2^{*} \\
6.5 \pm 0.3^{*} \\
0 \\
0.6 \pm 0.0^{*}\end{array}$ & $\begin{array}{l}5.1 \pm 0.3^{*} \\
5.0 \pm 0.6^{*} \\
-23 \\
0.4 \pm 0.0^{*}\end{array}$ & $\begin{array}{l}6.0 \pm 0.3 \\
6.8 \pm 0.4^{*} \\
0 \\
0.6 \pm 0.0^{*}\end{array}$ & $\begin{array}{l}5.9 \pm 0.2 \\
5.6 \pm 0.2 * \\
-17 \\
0.5 \pm 0.0 *\end{array}$ \\
\hline $\begin{array}{l}\text { Extractable } \mathrm{N}(\mathrm{mg} / \mathrm{kg}) \\
\text { Extractable } \mathrm{NO}_{3}-\mathrm{N}(\mathrm{mg} / \mathrm{kg}) \\
\text { Extractable } \mathrm{NH}_{4}-\mathrm{N}(\mathrm{mg} / \mathrm{kg})\end{array}$ & $\begin{array}{l}42.8 \pm 4.8^{*} \\
15.9 \pm 0.9^{*} \\
26.9 \pm 4.5^{*}\end{array}$ & $\begin{array}{r}21.0 \pm 2.6^{*} \\
6.7 \pm 1.9^{*} \\
14.3 \pm 2.0^{*}\end{array}$ & $\begin{array}{l}45.7 \pm 3.8^{*} \\
18.7 \pm 1.3^{*} \\
27.0 \pm 2.7\end{array}$ & $\begin{aligned} 30.6 & \pm 4.1^{*} \\
0.9 & \pm 0.6^{*} \\
29.7 & \pm 3.8\end{aligned}$ \\
\hline $\begin{array}{l}\text { Soil P }(\mu / \mathrm{g}) \\
\text { Bulk density } \\
\text { Total C }\left(\mathrm{kg} / \mathrm{m}^{2}\right) \\
\text { Total } \mathrm{N}\left(\mathrm{kg} / \mathrm{m}^{2}\right) \\
\text { Total P }\left(\mathrm{g} / \mathrm{m}^{2}\right)\end{array}$ & $\begin{array}{c}557.1 \pm 18.5 \\
0.52 \\
3.4 \\
0.3 \\
28.9\end{array}$ & $\begin{array}{c}639.5 \pm 51.8 \\
0.75 \\
3.7 \\
0.3 \\
33.2\end{array}$ & $\begin{array}{c}1051.4 \pm 43.1 \\
0.66 \\
4.5 \\
0.4 \\
69.4\end{array}$ & $\begin{array}{c}1228.0 \pm 88.7 \\
0.99 \\
5.5 \\
0.5 \\
81.0\end{array}$ \\
\hline \multicolumn{5}{|l|}{$P$ fraction $(\mu \mathrm{g} / \mathrm{g})$} \\
\hline $\begin{array}{l}\text { Resin } P_{i} \\
\text { Bicarb } P_{i} \\
\text { Bicarb } P_{o}\end{array}$ & $\begin{array}{r}4.2 \pm 0.4^{*} \\
3.4 \pm 0.1^{*} \\
13.7 \pm 0.6^{*}\end{array}$ & $\begin{array}{r}2.0 \pm 0.5^{*} \\
2.7 \pm 0.1^{*} \\
20.3 \pm 0.8^{*}\end{array}$ & $\begin{aligned} 8.9 & \pm 0.9 \\
5.1 & \pm 0.5^{*} \\
27.6 & \pm 1.1^{*}\end{aligned}$ & $\begin{array}{r}9.4 \pm 2.7 \\
7.4 \pm 1.7 * \\
33.5 \pm 0.9 *\end{array}$ \\
\hline
\end{tabular}

Notes: Table entries are means $\pm 1 \mathrm{SE}$ and represent eight samples per site. Abbreviations are: OF, oxisol forest; OP, oxisol pasture; MF, mollisol forest; MP, mollisol pasture; $\mathrm{P}_{\mathrm{i}}$, inorganic $\mathrm{P} ; \mathrm{P}_{\mathrm{o}}$, organic $\mathrm{P}$.

$* P<0.05$.

Soil $\mathrm{P}$ shows some striking differences between the forest and pasture sites (Table 1$)$. While total $P(\mu \mathrm{g} / \mathrm{g})$ values were not significantly different between $\mathrm{OF}$ and $\mathrm{OP}$, resin inorganic $\mathrm{P}\left(\mathrm{P}_{\mathrm{i}}\right)$ and bicarb $\mathrm{P}_{\mathrm{i}}$ in the $\mathrm{OF}$ forest site were both higher than the values for the same fraction in the OP pasture sites. Resin $\mathrm{P}_{\mathrm{i}}$ in the forest site was more than double the value observed in the OP site. In contrast to the inorganic fractions, the bicarb organic $\mathrm{P}\left(\mathrm{P}_{\mathrm{o}}\right)$ fraction at $\mathrm{OP}$ was significantly higher than at OF. On the mollisol soil, while total $\mathrm{P}$ was not significantly different at MF and MP, the patterns for labile $\mathrm{P}$ were opposite to those at the oxisol sites (Table 1). Specifically, bicarb $P_{i}$ and bicarb $P_{o}$ fractions were significantly higher at MP than at MF; resin $\mathrm{P}_{\mathrm{i}}$ was also higher at MP than at MF, although not significantly.

Phosphatase activity was consistently low across all sites (Table 2; Olander and Vitousek 2000). However, in the oxisol sites, phosphatase activity in the forest $(4.75 \pm 0.16$; mean $\pm 1 \mathrm{SE})$ was significantly higher than in the pasture $(4.12 \pm 0.12)$. In the mollisol sites, phosphatase activity was significantly higher in the pasture site $(5.16 \pm 0.36)$ than in the forest site $(3.40 \pm$ $0.31)$.

\section{Microbial $C$ and $N$}

Samples fumigated with chloroform were sampled in February 2000 (dry season) and in June 2000 (wet

TABLE 2. Seasonal phosphatase activity, extractable $\mathrm{C}$, microbial biomass and activity, and elemental ratios within the microbial biomass from forest and pasture sites on oxisol and mollisol soils in southwestern Costa Rica.

\begin{tabular}{|c|c|c|c|c|}
\hline \multirow[b]{2}{*}{ Parameter } & \multicolumn{4}{|c|}{ Site } \\
\hline & OF & $\mathrm{OP}$ & MF & MP \\
\hline \multicolumn{5}{|l|}{ February 2000 (dry season) } \\
\hline Soil moisture (\%) & 38.4 & 31.5 & 42.8 & 32.8 \\
\hline Ptase $\left(\mu \mathrm{mol} \mathrm{pNP} \cdot \mathrm{g}^{-1} \cdot \mathrm{h}^{-1}\right)$ & $4.8 \pm 0.2 *$ & $4.1 \pm 0.1 *$ & $3.4 \pm 0.3 *$ & $5.2 \pm 0.4^{*}$ \\
\hline Ptase $\left(\mu \mathrm{mol} \mathrm{pNP} \cdot \mu \mathrm{g}\right.$ microbial $\left.\mathrm{C}^{-1} \cdot \mathrm{h}^{-1}\right)$ & 0.005 & 0.008 & 0.003 & 0.007 \\
\hline Microbial C ( $\mu \mathrm{g} / \mathrm{g}$ soil $)$ & $952.3 \pm 46.7^{*}$ & $529.7 \pm 129.0^{*}$ & $991.5 \pm 95.0$ & $773.5 \pm 150.2$ \\
\hline Microbial C (mg/g soil C) & $14.7 \pm 7.2$ & $10.6 \pm 2.4$ & $14.6 \pm 1.4$ & $13.8 \pm 2.5$ \\
\hline Microbial C (\% change) & 0 & -28 & 0 & -5 \\
\hline Microbial N ( $\mu \mathrm{g} / \mathrm{g})$ & $251.3 \pm 6.1 *$ & $153.9 \pm 21.3^{*}$ & $231.3 \pm 15.9^{*}$ & $142.0 \pm 17.0^{*}$ \\
\hline \multicolumn{5}{|l|}{ June 2000 (wet season) } \\
\hline Soil moisture $(\%)$ & 51.4 & 40.3 & 46.0 & 47.3 \\
\hline Ptase $\left(\mu \mathrm{mol} \mathrm{pNP} \cdot \mathrm{g}^{-1} \cdot \mathrm{h}^{-1}\right)$ & $5.1 \pm 0.4$ & NA & $4.3 \pm 1.0$ & NA \\
\hline Microbial C ( $\mu \mathrm{g} / \mathrm{g}$ soil $)$ & $1967.0 \pm 119.7 *$ & $802.1 \pm 153.4^{*}$ & $1307.4 \pm 109.1$ & $1029.1 \pm 94.9$ \\
\hline Microbial C (mg/g soil C) & $30.3 \pm 1.9 *$ & $16.0 \pm 3.1^{*}$ & $19.2 \pm 1.6$ & $18.4 \pm 1.7$ \\
\hline Microbial C (\% change) & 0 & -47 & 0 & -4 \\
\hline Microbial N ( $\mu \mathrm{g} / \mathrm{g})$ & $324.1 \pm 18.1^{*}$ & $107.4 \pm 15.0 *$ & $221.1 \pm 20.2 *$ & $137.4 \pm 25.9^{*}$ \\
\hline
\end{tabular}

Notes: Table entries are means $\pm 1 \mathrm{SE}$ and represent the results of six samples per site. Abbreviations are: OF, oxisol forest; OP, oxisol pasture; MF, mollisol forest; MP, mollisol pasture; Ptase, phosphatase; pNP, p-nitrophenol. $* P<0.05$. 


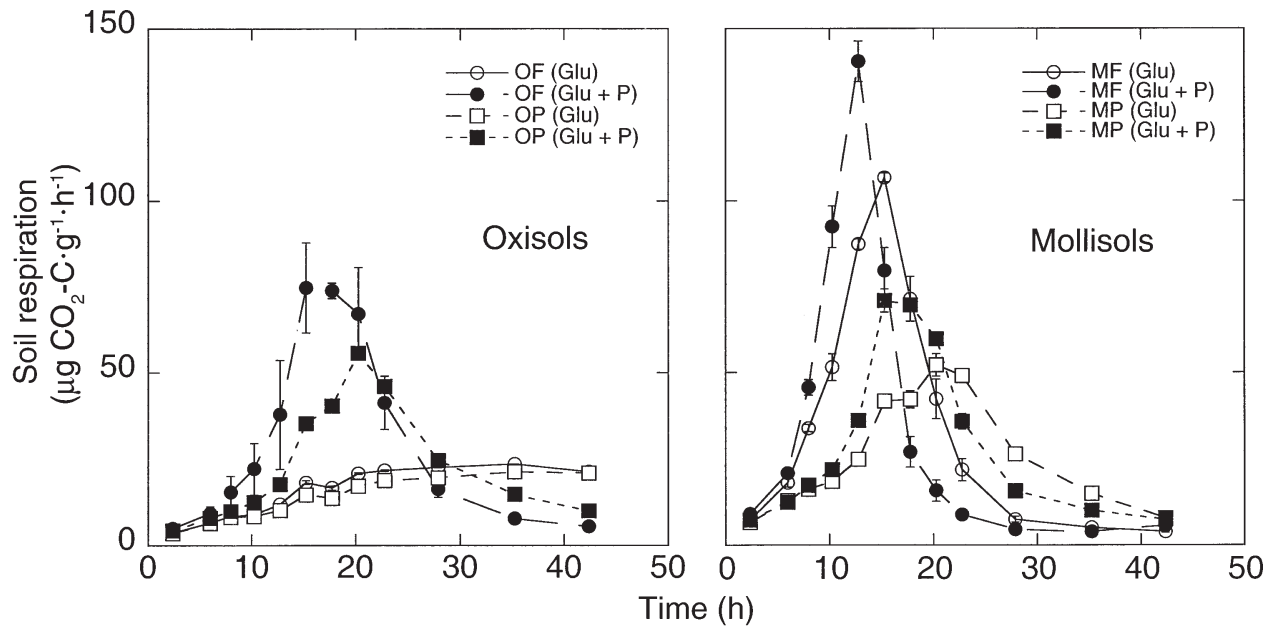

FIG. 2. Soil respiration rate following addition of ${ }^{14} \mathrm{C}$-labeled glutamate ("Glu"), with and without P, to forest and pasture soils from oxisol and mollisol sites. Circles represent forest sites, and squares represent pasture sites; open symbols represent the effects of $\mathrm{C}$ additions, and closed symbols represent the effects of $\mathrm{C}+\mathrm{P}$ additions. Error bars are $\pm 1 \mathrm{SE}$.

season). At all sites, microbial biomass $\mathrm{C}$ and $\mathrm{N}$ were consistently higher in soil sampled during the wet season, when soil moistures were all $>40 \%$. Seasonal patterns from the oxisol and mollisol sites are depicted in Table 2. Microbial biomass $\mathrm{C}$ and $\mathrm{N}$ were consistently significantly higher at OF than OP, regardless of season (Table 2). In the oxisol sites in February, microbial biomass $\mathrm{C}$ and $\mathrm{N}$ were both significantly higher in the forest site. In June, microbial biomass $\mathrm{C}$ at $\mathrm{OF}$ was nearly four times its value in February, and more than double the value at OP. Microbial biomass $\mathrm{N}$ at OF in June was also greater than its value in February, and greater than biomass $\mathrm{N}$ in the oxisol pasture.

At the mollisol sites, the spatial and seasonal patterns of microbial biomass $\mathrm{C}$ and $\mathrm{N}$ were less pronounced, although values at the mollisol sites were higher in June when soil moistures were greater (Table 2). In February, microbial biomass $\mathrm{C}$ at MF and MP were not significantly different, although microbial biomass $\mathrm{N}$ was significantly higher at MF than at MP (Table 2). In June, microbial biomass $\mathrm{C}$ was higher at MF than at MP, although not significantly. Similar to the patterns observed in February, microbial biomass $\mathrm{N}$ was significantly higher in June at MF than at MP.

\section{C substrate additions}

Previous work in these sites revealed that forest soil microbial community responses to $\mathrm{C}$ inputs are tightly constrained by $\mathrm{P}$ availability, especially in the oxisols (Cleveland et al. 2002). Here, we tested whether this constraint extended to pasture systems by adding multiple $\mathrm{C}$ substrates, with and without P. In the oxisol sites, both OP and OF showed a muted response to glutamate alone (Fig. 2, Table 3). However, when added in combination with $\mathrm{P}$, glutamate additions caused rapid responses in OP and OF (Fig. 2). While the response to added $\mathrm{P}$ was less striking in the mollisol sites, both the MP and MF site again responded more rapidly to glutamate additions in combination with labile $\mathrm{P}$ than with $\mathrm{C}$ alone (Fig. 2, Table 3).

We also performed a second set of incubations following the February 2000 sampling in which we added salicylate (instead of glutamate) to the soils. Salicylate is mineralized by the same general pathways as the breakdown products from lignin and detrital (poly-) phenols and was used to target a more specific group of microorganisms that may mineralize relatively recalcitrant plant detritus and humic materials. The salicylate additions were also done to test the effects of $\mathrm{P}$ additions without the simultaneous $\mathrm{N}$ additions that glutamate provides. The microbial responses to salicylate additions showed similar patterns to those observed with glutamate. Mineralization of salicylate was clearly limited by available $\mathrm{P}$ in the oxisols, and while the relative response was much smaller in the mollisols, $\mathrm{P}$ additions again had a significant effect on $\mathrm{C}$ processing in both MF and MP sites (Fig. 3).

Thus, $\mathrm{P}$ appears to constrain microbial activity in both forest and pasture systems, and on both soil types, although the relative responses to $\mathrm{P}$ do differ across the sites. Therefore, the remaining results depict the response of the soil microbial community to added $\mathrm{C}$ and $\mathrm{P}$. In other words, in order to investigate differences in microbial activity between sites without the fundamental and varying influence of $P$ constraints, we eliminated the possibility by adding labile $\mathrm{P}$ in the remainder of the experiments.

In June, glutamate additions to OF samples resulted in significantly higher rates of respiration throughout the incubation than in OP. In addition, the microbial community reached higher maximum growth rates, achieved higher maximum respiration rates, and suggested a more rapidly responding microbial community than in OP. In addition, while SIR values were higher 
TABLE 3. Seasonal indices of microbial activity following glutamate addition $(+\mathrm{P})$ to forest and pasture soils from oxisol and mollisol sites in southwestern Costa Rica.

\begin{tabular}{|c|c|c|c|c|}
\hline \multirow[b]{2}{*}{ Parameter } & \multicolumn{4}{|c|}{ Site } \\
\hline & OF & OP & MF & MP \\
\hline \multicolumn{5}{|l|}{ February 2000 (dry season) } \\
\hline Initial rate $\left(\mathrm{SIR} ; \mu \mathrm{g} \mathrm{CO}_{2}-\mathrm{C} \cdot \mathrm{g}^{-1} \cdot \mathrm{h}^{-1}\right)$ & $4.86 \pm 0.50$ & $4.28 \pm 0.06$ & $8.9 \pm 0.4$ & $7.3 \pm 0.1$ \\
\hline Biomass $(\mu \mathrm{g} / \mathrm{g})$ & $14.46 \pm 1.67^{*}$ & $27.61 \pm 3.01 *$ & $29.97 \pm 13.47$ & $29.35 \pm 5.83$ \\
\hline Growth rate $(/ \mathrm{h})$ & $0.20 *$ & $0.13 *$ & $0.24 *$ & $0.16^{*}$ \\
\hline $\begin{array}{l}\text { Maximum respiration rate } \\
\left(\mu \mathrm{g} \mathrm{CO} \mathrm{C}_{2}-\mathrm{C} \cdot \mathrm{g}^{-1} \cdot \mathrm{h}^{-1}\right)\end{array}$ & $74.72 \pm 13.13^{*}$ & $55.56 \pm 0.99^{*}$ & $140.5 \pm 5.9^{*}$ & $70.9 \pm 3.4^{*}$ \\
\hline $\mathrm{C}$ respired $(\%)$ & 57.30 & 51.03 & 63.19 & 56.44 \\
\hline \multicolumn{5}{|l|}{ June 2000 (wet season) } \\
\hline Initial rate $\left(\mathrm{SIR} ; \mu \mathrm{g} \mathrm{CO}_{2}-\mathrm{C} \cdot \mathrm{g}^{-1} \cdot \mathrm{h}^{-1}\right)$ & $8.1 \pm 0.9 *$ & $3.7 \pm 0.5^{*}$ & $15.0 \pm 0.8^{*}$ & $10.1 \pm 0.4^{*}$ \\
\hline Biomass $(\mu \mathrm{g} / \mathrm{g})$ & $44.62 \pm 9.24 *$ & $23.49 \pm 3.95^{*}$ & $120.01 \pm 34.91 *$ & $40.11 \pm 7.05^{*}$ \\
\hline Growth rate $(/ \mathrm{h})$ & 0.14 & 0.13 & $0.14 *$ & $0.17 *$ \\
\hline 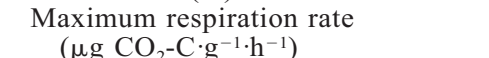 & $73.7 \pm 0.6^{*}$ & $60.0 \pm 1.2^{*}$ & $86.3 \pm 0.2$ & $84.5 \pm 1.4$ \\
\hline $\mathrm{C}$ respired $(\%)$ & 54.0 & 52.4 & 52.4 & 51.2 \\
\hline
\end{tabular}

Notes: Table entries are means $\pm 1 \mathrm{SE}$ and represent the results from duplicate samples. Abbreviations are: OF, oxisol forest; OP, oxisol pasture; MF, mollisol forest; MP, mollisol pasture; SIR, substrate-induced respiration.

$* P<0.05$.

in OF than OP (Table 3), initial glutamate mineralizer biomass was actually lower in OF than OP, eliminating the possibility that our results depict merely a biomass effect. In the wet season (June), glutamate mineralizer biomass at OF was nearly twice that in OP, and nearly three times the value observed in February. In contrast, pasture biomass changes little seasonally in the oxisol sites. However, unlike the dry season, maximum growth rates did not differ between oxisol forest and pasture sites.

In the mollisol sites in February (dry season), the microbial community at MF responded with higher SIR values, higher maximum respiration rates, higher growth rates, and higher proportions of $\mathrm{C}$ utilized than at MP over the course of the experiment (Fig. 2, Table 3 ), in spite of nearly identical glutamate mineralizer biomass estimates. In June, as in the oxisols, glutamate mineralizer biomass increases dramatically in the forest; pasture biomass in June is slightly greater than its February value. Again, as with the oxisols, maximum growth rates of the microbial community at MP vary little seasonally, while the June MF value is significantly lower than the February MF value and the June pasture value.

Salycilate additions to oxisol soil (dry season) also revealed differences between forest and pasture sites (Fig. 3, Table 4). Specifically, over the course of the experiment, the salycilate-degrading functional group at OF had higher initial respiration rates, achieved higher growth rates, reached higher maximum respiration rates, and mineralized a greater percentage of the added substrate than the microbial community at

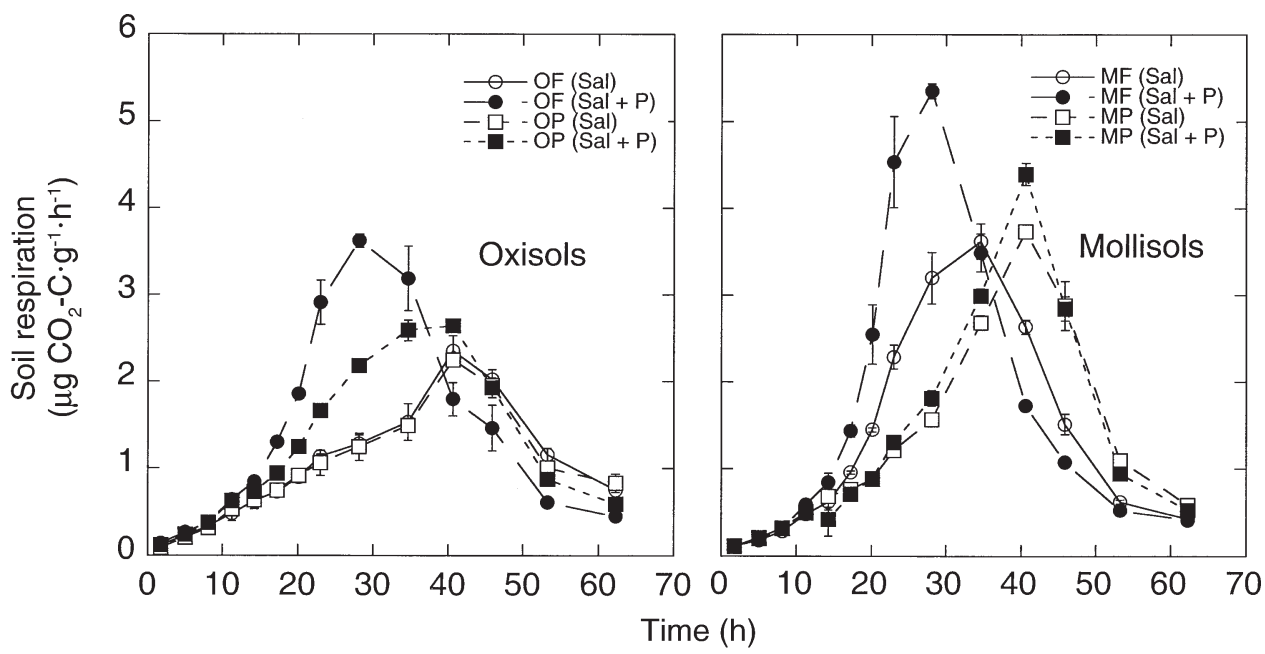

FIG. 3. Soil respiration rate following addition of ${ }^{14} \mathrm{C}$-labeled salicylate ("Sal"), with and without $\mathrm{P}$, to forest and pasture soils from oxisol and mollisol sites. Circles represent forest sites, and squares represent pasture sites; open symbols represent the effects of $\mathrm{C}$ additions, and closed symbols represent the effects of $\mathrm{C}+\mathrm{P}$ additions. Error bars are \pm 1 SE. 
TABLE 4. Dry-season indices of microbial activity following salicylate addition $(+\mathrm{P})$ to forest and pasture soils from oxisoland mollisol sites in southwestern Costa Rica.

\begin{tabular}{lcccc}
\hline \hline & \multicolumn{4}{c}{ Site } \\
\cline { 2 - 5 } Parameter & OF & OP & MF & MP \\
\hline February 2000 (dry season) & & & & \\
Initial rate $\left(\mathrm{SIR} ; \mu \mathrm{g} \mathrm{CO}_{2}-\mathrm{C} \cdot \mathrm{g}^{-1} \cdot \mathrm{h}^{-1}\right)$ & $0.14 \pm 0.00^{*}$ & $0.12 \pm 0.00^{*}$ & $0.11 \pm 0.01$ & $0.11 \pm 0.00$ \\
SIGR biomass $\left(\mu \mathrm{g} \mathrm{CO}_{2}-\mathrm{C} / \mathrm{g}\right)$ & $2.48 \pm 0.84$ & $2.76 \pm 0.54$ & $2.23 \pm 1.24$ & $1.67 \pm 0.34$ \\
Biomass $(\mu \mathrm{g} / \mathrm{g})$ & $0.31 \pm 0.10$ & $0.34 \pm 0.07$ & $0.27 \pm 0.15$ & $0.21 \pm 0.04$ \\
Growth rate $(/ \mathrm{h})$ & $0.10^{*}$ & $0.08^{*}$ & $0.11^{*}$ & $0.09^{*}$ \\
Maximum respiration rate $\left(\mu \mathrm{g} \mathrm{CO}_{2}-\mathrm{C} \cdot \mathrm{g}^{-1} \cdot \mathrm{h}^{-1}\right)$ & $3.62 \pm 0.08^{*}$ & $2.63 \pm 0.06^{*}$ & $5.35 \pm 0.08^{*}$ & $4.39 \pm 0.13^{*}$ \\
$\mathrm{C}$ respired $(\%)$ & 48.22 & 41.11 & 55.51 & 46.54 \\
\hline
\end{tabular}

Notes: Table entries are means $\pm 1 \mathrm{SE}$ and represent the results from duplicate samples. Abbreviations are: OF, oxisol forest; OP, oxisol pasture; MF, mollisol forest; MP, mollisol pasture; SIR, substrate-induced respiration; SIGR, substrateinduced growth response.

$* P<0.05$.

OP, even though the salycilate-degrading biomass was not different between the two sites (Table 4).

In the mollisol sites, the microbial community at MF again appeared to respond more rapidly than at MP. Salycilate mineralizers at MF had higher growth rates, higher maximum respiration rates, and respired more salycilate than at MP. However, while not significant, initial salycilate mineralizer biomass was higher at MF than MP, which may influence the higher maximum respiration rate seen at MF (Table 4).

\section{Discussion}

\section{Soil physical and biogeochemical characteristics}

Management intensity in our Costa Rican pasture sites is relatively light compared to many other tropical pasture systems. For example, grazing rates are low, despite a favorable climate with a short dry season, and burning is not used as a management tool to reduce weedy in-growth, thus eliminating a major pathway for the loss of key elements (Kauffman et al. 1995, 1998). We chose lightly managed sites on purpose, to explore whether even less intense land use would still lead to significant biogeochemical and/or microbial changes.

Despite the light management, we observed a variety of significant changes in soil properties and major biogeochemical cycles between forest and pasture on each soil type. Many of these changes are discussed in greater detail in Townsend et al. (2002); here, we report some additional data, and the major patterns in soil physical and biogeochemical characteristics are summarized in Table 1. We observed increases in soil bulk density, which may be suggestive of significant soil compaction during pasture use (Veldkamp 1994, de Moraes et al. 1996). Soil $\mathrm{pH}$ also changed from forest to pasture, but unlike most reports (e.g., Reiners et al. 1994), we observed decreases in $\mathrm{pH}$ in each pasture, although only the oxisol change was significant. The lack of burning as a management strategy in the pasture systems in Costa Rica may preclude the increase in $\mathrm{pH}$ commonly observed in tropical systems, and may help explain the declines in our sites.
Past studies of $\mathrm{C}$ stocks following conversion of tropical forest to pasture have shown a range of responses, including increases, decreases, or no net longterm changes in soil C (Cerri et al. 1991, Tiessen et al. 1992, Trumbore et al. 1995, de Moraes et al. 1996, Neill et al. 1997). In our lightly managed sites, significant declines in soil $\mathrm{C}$ (percent) are balanced out (and likely partly caused) by increased bulk density and soil compaction, resulting in no significant changes in total soil organic carbon (SOC) in either soil type (Table 1). However, we did observe significant changes in both nitrogen and phosphorus cycling in each forestpasture comparison.

In general, our pasture sites showed smaller pools of extractable $\mathrm{N}$ relative to their forest counterparts. In addition, we observed that in both oxisol and mollisol sites, $\mathrm{NO}_{3}{ }^{-}$pools were higher in forests than pastures, and at least in the mollisol sites, $\mathrm{NH}_{4}{ }^{+}$was higher in the pasture than in the forest. As suggested in previous studies, these data support decreased rates of plant $\mathrm{NH}_{4}{ }^{+}$uptake, and/or decreased rates of nitrification in pastures, and perhaps decreases in the overall rate of $\mathrm{N}$ cycling in pastures relative to forests (Vitousek 1984, Vitousek and Sanford 1986, Matson et al. 1987, Reiners et al. 1994, Neill et al. 1996).

Numerous studies have suggested that P limits ecosystem processes in tropical forest ecosystems, and that conversion of forest to pasture may exacerbate P constraints (Tiessen et al. 1992, Townsend et al. 2002). Not surprisingly, the most striking biogeochemical difference between the forest and pasture sites, particularly in the oxisol sites, was related to P status. First, in the oxisol sites, which represent the dominant soil type in this area and in the humid tropics globally, resin-extractable inorganic $\mathrm{P}$ in the pasture was less than half the value of its forest counterpart. As well, the OP site had significantly less $(\sim 20 \%)$ inorganic bicarbonate-extractable $\mathrm{P}$ than the oxisol forest site. The sum of resin- and bicarbonate-extractable inorganic $\mathrm{P}$ are often taken as the best index of plantavailable P (Bowman et al. 1978, Levy and Schlesinger 
1999), thus, despite no declines in total soil organic matter (SOM), forest-to-pasture conversion in the oxisols appears to have caused significant declines in $\mathrm{P}$ fertility. Third, organic forms of $\mathrm{P}$ increase from $\mathrm{OF}$ to $\mathrm{OP}$, and total soil $\mathrm{P}$ increases. All forms of $\mathrm{P}$ measured were higher in the mollisol sites, perhaps reflecting alluvial inputs of $\mathrm{P}$ in this lowland site, combined with lower biomass $\mathrm{P}$ uptake in the MP relative to the MF site.

\section{Soil microbial community structure and function}

While P limitation to microbial processes has been demonstrated in forest systems (Cleveland et al. 2002), our data suggest such constraints are also present in the pastures. Even in the (relatively) P-rich mollisol site, responses to $\mathrm{C}$ inputs are greater with $\mathrm{P}$ additions in both forest and pasture systems (Fig. 2). Thus, following conversion, $\mathrm{P}$ limitation of the microbial community appears to remain in spite of simultaneous increases in organic and total P. This may indicate the importance of available $\mathrm{P}$ in regulating microbial processes in both forest and pasture systems even on soils that are relatively rich in $\mathrm{P}$.

Our results also suggest that conversion of forest to pasture can lead to dramatic changes in the overall size of the microbial community. In the oxisol pasture, microbial $\mathrm{C}$ was between $45 \%$ and $60 \%$ lower than values in the forest (on a per gram soil basis), depending on season. In addition, our analysis suggests that the observed decrease in microbial biomass was not driven entirely by changes in SOM between forest and pasture sites. In the oxisol sites, SOM decreased by $23 \%$ from forest to pasture (Table 1). However, on a per gram C basis, the decreases in microbial biomass from forest to pasture are greater. In February, microbial biomass decreased by $47 \%$ from forest to pasture, and in June, by $69 \%$ from forest to pasture. Thus, while a change in soil $\mathrm{C}$ from forest to pasture may explain some of the decrease in microbial biomass, the much larger declines in microbial biomass suggest that they are driven by environmental changes beyond those in their primary energy source.

Microbial biomass $\mathrm{C}$ also appears to decline from forest to pasture in the mollisols, although the difference in total biomass is not significant (Table 2). In addition, in the mollisol sites, on a per gram of soil $\mathrm{C}$ basis, microbial biomass does not decrease to the same extent that SOC decreases from forest to pasture, and the differences do not change seasonally. This difference does not change seasonally. Thus, it appears that these relatively rich sites are more "stable" than the nutrient-poor oxisol sites, but still not immune to changes in the microbial community as a consequence of forest-to-pasture conversion.

Overall, our results suggest a possible gradient in the response of microbial communities to land use change, in which the impacts range from large in nutrient-poor sites to relatively modest in more fertile sites. While studies such as this are relatively rare, most of those that do exist also demonstrate that conversion of natural vegetation to used land on nutrient-poor soils, as well as agricultural intensification, leads to significant decreases in microbial biomass (Luizao et al. 1992, Henrot and Robertson 1994). In contrast, Groffman et al. (2001) found that land conversion did not decrease microbial biomass and activity in a relatively nutrient-rich tropical riparian ecosystem in Costa Rica. This is practically relevant, given that moderately fertile soils (such as mollisols) are uncommon in the humid tropics, comprising $<15 \%$ of the total land (Sanchez et al. 1982, Vitousek and Sanford 1986). In contrast, soils of low fertility (oxisols and ultisols) represent the most abundant soil types in tropical ecosystems (Vitousek and Sanford 1986). As much of the fertile land has already been converted to agriculture, future development of new agricultural lands within the humid tropics will undoubtedly be forced onto lowfertility soils (Sanchez et al. 1982). Our results suggest that conversion of land on infertile soil may have much more profound consequences for microbial communities and biogeochemical cycling than has been observed on more fertile soils. In addition, management intensity in our Costa Rican pasture sites is relatively light compared to many other tropical pasture systems. Thus, we would also expect that the effects of more intense management strategies (e.g., periodic fire to control weed growth) would have an even greater impact on the soil microbial community than we observed in these sites.

Clearly, the conversion of forest to pasture causes significant changes to the soil environment, leading to changes in soil carbon sources, nutrient availability, $\mathrm{pH}$, and bulk density, among others. Not surprisingly, a few recent studies have shown that the conversion of forest to pasture in tropical rain forest ecosystems often induces wholesale changes in belowground microbial community composition. For example, Nüsslein and Tiedje (1999) showed that a change from forest to pasture in Hawaii led to a significant change in the dominant bacterial phyla, and resulted in a $49 \%$ shift in overall microbial composition. In addition, bacterial DNA analysis has shown substantial differences in community composition between forest and pasture sites (Borneman and Triplett 1997), with forest sites displaying greater species diversity and redundancy in physiological groups than disturbed pasture sites. The decrease in diversity may result from mineral leaching, lowered SOM content, differing plant organic inputs, or lowered soil aeration caused by soil compaction and loss of structure following conversion (e.g., Vazquez et al. 1993).

Our incubation data with radiolabeled glutamate provide further evidence of community compositional changes following land conversion. For example, in the oxisols in February, glutamate additions revealed that the forest microbial community responded more rapidly, grew faster, reached higher maximum rates of res- 
piration, and respired a greater percentage of added labile $\mathrm{C}$ than did the pasture communities, in spite of the fact that initial glutamate mineralizer biomass was actually lower in the forest than in the pasture (Fig. 2, Table 3). Glutamate additions to the mollisols showed a similar pattern, suggesting that, at least in the dry season, the mollisol forest is characterized by a physiologically different, more responsive community than is the mollisol pasture (Table 3). Thus, not only are forests characterized by higher total microbial biomass (chloroform labile), but our SIGR incubations suggest that pastures and forest are also characterized by physiologically different (and hence compositionally different) microbial communities.

In addition, our results suggest strong seasonal fluctuations in the forest communities, which appear to be absent in the pasture sites. For example, in June, glutamate mineralizer biomass increased three-fold in the oxisol forest and more than four-fold in the mollisol forest, but stayed relatively constant in the oxisol pasture and the mollisol pasture (Table 2). In addition, growth rates of the glutamate-responsive microbial community varied considerably seasonally in both forests, but stayed relatively unchanged in the pasture sites. These results suggest that the microbial communities as a whole in the native forest sites are plastic and responsive to seasonal changes (e.g., in resource availability). In contrast, the SIGR assays suggest that the microbial communities at the pasture sites are much more physiologically static. We hypothesize that the seasonal variability in microbial physiological parameters observed is indicative of a more compositionally diverse community in the forests than in the pastures. Clearly, there are dramatic decreases in plant diversity following the conversion of a primary rainforest to a grass monoculture. This change in itself almost certainly leads to changes in microbial community composition, and in fact has been demonstrated in similar systems (Borneman and Triplett 1997, Nüsslein and Tiedje 1999). While we have no direct evidence to support this hypothesis here, our data do suggest important physiological differences between forest and pasture communities, and support the notion that forest-to-pasture conversion leads to changes in not only the size, but also the composition, of the soil microbial community.

We also found that forest-to-pasture conversion not only led to decreases in the magnitude, functional composition, and activity of the microbial community as a whole, but also to declines in a specific functional group. Salicylate is mineralized by the same general pathways as breakdown products from lignin and detrital polyphenols, and its addition can be a test of more restricted microbial communities that process this recalcitrant material (Ley et al. 2001). As with glutamate, following salicylate additions, the microbial community in both oxisol and mollisol pastures responded more slowly, grew more gradually, showed lower max- imum respiration rates, and respired a lower percentage of added salicylate than the forest microbial community, despite no significant differences in initial salycitale mineralizer biomass (Fig. 3, Table 4). This apparent decline in a group that occupies a relatively specific biogeochemical niche further supports previous research demonstrating that land conversion not only decreases the magnitude of the microbial community, but also the alters its dominant composition and physiology (Borneman and Triplett 1997, Nüsslein and Tiedje 1999).

\section{Implications for biogeochemical cycling}

We believe that the observed changes in microbial community structure and function observed here may help explain biogeochemical patterns observed here and in other studies. For example, the fact that organic and total $\mathrm{P}$ pools can increase along forest-pasture chronosequences (Garcia-Montiel et al. 2000, Townsend et al. 2002) suggests that the conversion of forest to pasture could increase the $\mathrm{P}$ fertility of a given site. However, over time, plants on converted sites (including ours) often show strong signs of increasing P limitation (e.g., Asner et al. 1999), concomitant with sizeable, significant decreases in forms of $\mathrm{P}$ available to plants. Since inorganic P either remained constant or declined with pasture age in our sites, while organic $\mathrm{P}$ increased, it seems clear that the rate at which organic $\mathrm{P}$ is mineralized must decline, especially on the oxisols. The increases in organic $\mathrm{P}$ are not simply due to new inputs, because they are not matched by increases in total organic matter. Instead, the rate at which organic $\mathrm{P}$ is converted to inorganic forms must decrease to produce the patterns we report. Phosphorus mineralization can occur via the production of extracellular phosphatases by plant roots (Speir and Cowling 1991); therefore, a change from forest to pasture vegetation may be partly responsible for a decline in mineralization rates. However, we suggest that the observed changes in the structure, functional composition, and activity of the soil microbial community following conversion of forest to pasture may play a major role in changing the $\mathrm{P}$ cycle and producing the patterns we report.

For example, our results showed that extracellular phosphatase activity in the oxisol forest was significantly higher than in the oxisol pasture on a per gram soil basis. In contrast, phosphatase production on a biomass basis actually increased from forest to pasture on both oxisols and mollisols (Table 2). One would expect that a decline in labile inorganic $\mathrm{P}$, along with an increase in organic P (as seen in the oxisol pasture), should trigger higher rates of phosphatase activity (McGill and Cole 1981). However, although phosphatase per unit biomass increased (thus suggesting that soil $P_{i}$ status should increase), the dramatic declines in $\mathrm{mi}-$ crobial biomass lead to the observed net decrease in phosphatase production on a per gram soil basis. Thus, 
the decrease in the size of the microbial community from the oxisol forest to the oxisol pasture may lead to the decreases in the plant-available inorganic $\mathrm{P}$ we observed in the pasture. If so, this would provide a direct linkage between a perturbation of a microbial community (a decrease in total biomass) and a biogeochemical consequence (a net decrease in $\mathrm{P}_{\mathrm{i}}$ production via phosphatase activity).

Changes in the structure and function of the microbial community following land conversion may also have important implications for $\mathrm{C}$ cycling, and suggest a possible mechanism for some of the observations obtained here and in other studies in similar systems. For example, many studies have shown substantial declines in soil $\mathrm{C}$ immediately following conversion, but that soil $\mathrm{C}$ reserves recover after a relatively short period of time (e.g., Cerri et al. 1991, Neill et al. 1996, 1997). Some studies have suggested that this gradual increase in pasture soil $\mathrm{C}$ following conversion results from slow, but continuous increasing inputs of organic matter from litterfall and turnover of root biomass (e.g., Tiessen et al. 1994). However, our results provide an additional possible mechanism. Over time, the depressed rate of $\mathrm{C}$ mineralization we observed in the pasture soils, if a common pattern following land use change, could prevent even further declines in SOC in some sites, and facilitate the increases in soil $\mathrm{C}$ sometimes observed in others. In other words, we suggest that, while declining SOC pools can certainly drive declines in microbial biomass, the reverse can also be true. For example, our data show far more dramatic declines in microbial pools than in total SOC, suggesting that much of the microbial response to land conversion is due to changes in variables other than SOC. The net effect of a greatly reduced microbial pool may, in turn, be to reduce overall SOC decomposition rates, simply due to first-order kinetic relationships between the size of the decomposer pool and $\mathrm{C}$ mineralization.

Next, in the tropics, the combination of intense but episodic precipitation events and a large standing pool of carbon in leaf litter make it likely that microbial populations experience frequent inputs of high quality $\mathrm{C}$ as dissolved organic carbon (DOC) flushes through surface soils (Jandl and Sollins 1997). As well, exudation of labile $\mathrm{C}$ from roots can be a significant carbon flux in many ecosystems (Biondini et al. 1988). Based on our results, the fate of this excess $C$ in pasture systems (at least on oxisols) may be very different from that seen in the forest ecosystems where microbial activity responds more rapidly to $\mathrm{C}$ inputs. We also suggest that during periods of high $\mathrm{C}$ availability, diminished $\mathrm{C}$ mineralization rates in pasture soils could cause some fraction of labile DOC flushes to remain within the ecosystem for longer periods of time. Longer residence times for such $\mathrm{C}$ could increase the odds for its stabilization in soils (Neff and Asner 2000), thus lead- ing to increases in soil organic $\mathrm{C}$ over time, and/or increasing potential losses via DOC leaching.

The diminished ability of the pasture microbial communities to respond to $\mathrm{C}$ inputs also has some potential implications for $\mathrm{P}$ cycling, and could contribute to the declines in plant-available $\mathrm{P}$ observed in pastures here and elsewhere. In the highly sorbing, phosphorus-poor soils of the humid tropics, the microbial community may serve as a valve connecting above- and belowground nutrient cycling, providing a critical nutrient conservation system in P-poor oxisols and ultisols. Perturbation to the microbial community may damage this valve, leading to fundamental changes in the biogeochemical cycling of phosphorus. For example, the association of $\mathrm{P}$ with soil DOC, either as part of those molecules or electrostatically adsorbed by DOC, would render this otherwise immobile element mobile, and therefore subject to leaching (Donald et al. 1993). In addition, if such dissolved organic matter (DOM) is characterized by relatively low $\mathrm{C}: \mathrm{P}$ ratios, losses of DOM may lead to decreases in plant available forms of P like those observed in this and other studies (Asner et al. 1999, Garcia-Montiel 2000, Townsend et al. 2002). The observed decrease in microbial efficiency following labile and recalcitrant $\mathrm{C}$ additions in the pastures supports this possibility.

We also observed forest to pasture decreases in a functional group that is at least partially responsible for the decomposition of more recalcitrant organic compounds (e.g., lignin and detrital polyphenols). This result suggests a shift in the microbial community from one that is adapted to degrading recalcitrant, ligninrelated compounds in the forest to one that is less able to decompose such recalcitrant compounds in pasture communities (Cerri et al. 1991). Since C and P cycling are closely related, changes in microbial functional groups may not only affect $\mathrm{C}$ cycling, but also the cycling of P. Donald et al. (1993) found that recalcitrant, hydrophobic-neutral dissolved organic matter (i.e., lignin by-products) is often P-rich and is not readily sorbed in the soil. If changes in the microbial community lead to decreases the efficiency of the biological mineralization of such compounds (like those we observed following salicylate additions), leaching of these high molecular weight, P-rich, and potentially mobile hydrophobic-neutral compounds may be in part responsible for the losses of plant-available $\mathrm{P}$ often seen in pasture systems, and we believe the possibility merits further investigation.

\section{ACKNOWLEDGMENTS}

We thank Herbert and Marleny Michaud for access, logistical support, and use of field sites; the Organization for Tropical Studies and the Ministerio de Ambiente Energia (MINAE) in Costa Rica for facilitating all aspects of the field research; Maggie Lefer, Keri Holland, Ruth Ley, and David Lipson for assistance with lab and field work. We also acknowledge the support of the Andrew W. Mellon Foundation (A. R. Townsend), NSF Grant DEB-0089447 (A. R. Townsend and S. K. Schmidt), a University of Colorado Junior 
Faculty Development Award (A. R. Townsend), and a Biosphere-Atmosphere Research Training Grant (C. C. Cleveland) to the University of Colorado from the National Science Foundation (BIR-9413218).

\section{Literature Cited}

Asner, G. P., A. R. Townsend, and M. C. Bustamante. 1999. Spectrometry of pasture condition and biogeochemistry in the Central Amazon. Geophysical Research Letters 26 : 2769-2772.

Berrange, J. P., and R. S. Thorpe. 1988. The geology, geochemistry, and emplacement of the Cretaceous-Tertiary ophiolitic Nicoya Complex of the Osa Peninsula, southern Costa Rica. Tectonophysics 147:193-220.

Biondini, M., D. A. Klein, and E. F. Redente. 1988. Carbon and nitrogen losses through root exudation by Agropyron cristatum, Agropyron smithii, and Bouteloua gracilis. Soil Biology and Biochemistry 20:477-482.

Borneman, J., and E. W. Triplett. 1997. Molecular microbial diversity in soils from eastern Amazonia. Applied and Environmental Microbiology 63:2647-2653.

Bowman, R. A., S. R. Olson, and F. S. Watanabe. 1978. Greenhouse evaluation of residual phosphate by four phosphorus methods in neutral and calcareous soils. Soil Science Society of America Journal 42:451-454.

Brookes, P. C., A. Landman, G. Pruden, and D. S. Jenkinson. 1985. Chloroform fumigation and the release of soil nitrogen: a rapid direct extraction method to measure microbial biomass nitrogen in soil. Soil Biology and Biochemistry 17:837-842.

Buschbacher, R., C. Uhl, and E. A. S. Serrao. 1988. Abandoned pastures in eastern Amazonia. II. Nutrient stocks in the soil and vegetation. Journal of Ecology 776:682-699.

Cerri, C. C., B. Volkoff, and F. Andreaux. 1991. Nature and behaviour of organic matter in soils under natural forest, and after deforestation, burning and cultivation, near Manaus. Forest Ecology and Management 38:247-257.

Cleveland, C. C., A. R. Townsend, and S. K. Schmidt. 2002. Phosphorus limitation of microbial activity in lowland moist tropical forests. Ecosystems 5:680-691.

Colores, G. M., S. K. Schmidt, and M. C. Fisk. 1996. Estimating the biomass of microbial functional groups using rates of growth-related soil respiration. Soil Biology and Biochemistry 28:1569-1577.

Davidson, E. A., D. C. Nepstad, C. Klink, and S. E. Trumbore. 1995. Pasture soils as a carbon sink. Nature 376:472-473.

D'Elia, C. F., P. A. Steudler, and N. Corwin. 1977. Determination of total nitrogen in aqueous samples using persulfate digestion. Limnol. Oceanogr. 22:760-764.

de Moraes, J. L., B. Volkoff, C. C. Cerri, and M. Bernoux. 1996. Soil properties under Amazon forest and changes due to pasture installation in Rondonia, Brazil. Geoderma 70:63-81.

Donald, R. G., D. W. Anderson, and J. W. B. Stewart. 1993. Potential role of dissolved organic carbon in phosphorus transport in forested soils. Soil Science Society of America Journal 57:1611-1618.

Eden, M. J., P. A. Furley, D. F. M. McGregor, W. Milliken, and J. A. Ratter. 1991. Effect of forest clearance and burning on soil properties in northern Roraima, Brazil. Forest Ecology and Management 38:283-290.

Ekelund, F., R. Ronn, and S. Christensen. 2001. Distribution with depth of protozoa, bacteria, and fungi in soil profiles from three Danish forest sites. Soil Biology and Biochemistry 33:475-481.

Fearnside, P. M. 1996. Amazonian deforestation and global warming: carbon stocks in vegetation replacing Brazilian Amazon forest. Forest Ecology and Management 80:2134.

Garcia-Montiel, D. C., C. Neill, J. Melillo, S. Thomas, P. A Steudler, and C. C. Cerri. 2000. Soil phosphorus transfor- mations following forest clearing for pasture in the Brazilian Amazon. Soil Science Society of America Journal 64:1792-1804.

Groffman, P. M., W. H. McDowell, J. C. Meyers, and J. L. Merriam. 2001. Soil microbial biomass and activity in tropical riparian forests. Soil Biology and Biochemistry 33: 1339-1348.

Henrot, J., and G. P. Robertson. 1994. Vegetation removal in two soils of the humid tropics: effect on microbial biomass. Soil Biology and Biochemistry 26:111-116.

Holdridge, L. R., W. C. Grenke, W. H. Hatheway, T. Liang, and J. A. Tosi. 1971. Forest environments in tropical life zones: a pilot study. Pergamon Press, Oxford, UK.

Houghton, R. A. 1994. The worldwide extent of land-use change. Bioscience 44:305-313.

Jandl, R., and P. Sollins. 1997. Water-extractable soil carbon in relation to the belowground carbon cycle. Biology and Fertility of Soils 25:196-201.

Kauffman, J. B., D. L. Cummings, and D. E. Ward. 1995 Fire in the Brazilian Amazon: biomass, nutrient pools and losses in cattle pastures. Oecologia 104:397-411.

Kauffman, J. B., D. L. Cummings, and D. E. Ward. 1998. Fire in the Brazilian Amazon: 2. Biomass, nutrient pools and losses in cattle pastures. Oecologia 113:415-427.

Kuo, S. 1996. Phosphorus. Pages 869-919 in D. L. Sparks, A. L. Page, P. A. Helmke, R. H. Loepper, P. N. Soltanpour, M. A. Tabatabai, C. T. Johnston, and M. E. Sumner, editors. Methods of soil analysis. Part 3: chemical methods. Soil Science Society of America, Madison, Wisconsin, USA.

Levy, E. T., and W. S. Schlesinger. 1999. A comparison of fractionation methods for forms of phosphorus in soil. Biogeochemistry 47:25-38.

Ley, R. E., D. A. Lipson, and S. K. Schmidt. 2001. Microbial biomass levels in barren and vegetated high altitude talus soils. Soil Science Society of America Journal 65:111-117.

Lipson, D. A., S. K. Schmidt, and R. K. Monson. 1999. Links between microbial population dynamics and nitrogen availability in an alpine ecosystem. Ecology 80:1623-1631.

Luizao, R. C. C., T. A. Bonde, and T. Rosswall. 1992. Seasonal variation of soil microbial biomass - the effects of clearfelling a tropical rain forest and establishment of pasture in the central Amazon. Soil Biology and Biochemistry 24:805-813.

Matson, P. A., W. J. Parton, A. G. Power, and M. J. Swift. 1997. Agricultural intensification and ecosystem properties. Science 277:504-509.

Matson, P. A., P. M. Vitousek, J. J. Ewel, M. J. Mazzarino, and G. P. Robertson. 1987. Nitrogen transformations following tropical forest felling and burning on a volcanic soil. Ecology 68:491-502.

McGill, W. B., and C. V. Cole. 1981. Comparative aspects of cycling of organic $\mathrm{C}, \mathrm{N}, \mathrm{S}$, and $\mathrm{P}$ through soil organic matter. Geoderma 26:267-286.

Neff, J. C., and G. P. Asner. 2000. Dissolved organic carbon in terrestrial ecosystems: synthesis and a model. Ecosystems 4:29-48.

Neill, C., B. Fry, J. M. Melillo, P. A. Steudler, J. F. L. de Moraes, and C. C. Cerri. 1996. Forest- and pasture-derived carbon contributions to carbon stocks and microbial respiration of tropical pasture soils. Oecologia 107:113-119.

Neill, C., J. M. Melillo, P. A. Steudler, C. C. Cerri, J. F. L. de Moraes, M. C. Piccolo, and M. Brito. 1997. Soil carbon and nitrogen stocks following forest clearing for pasture in the southwestern Brazilian Amazon. Ecological Applications 7:1216-1225.

Nepstad, D. C., A. Veríssimo, A. Alencar, C. Nobre, E. Lima, P. Lefebvre, P. Schlesinger, C. Potter, P. Moutinho, E. Mendoza, M. Cochrane, and V. Brooks. 1999. Large-scale impoverishment of Amazonian forests by logging and fire. Nature 398:505-508. 
Nepstad, D. C., C. Uhl, and E. A. S. Serrao. 1991. Recuperation of a degraded Amazonian landscape: forest recovery and agricultural restoration. Ambio 20:248-255.

Nüsslein, K., and J. M. Tiedje. 1999. Soil bacterial community shift correlated with change from forest to pasture vegetation in a tropical soil. Applied and Environmental Microbiology 65:3622-3626.

Olander, L. P., and P. M. Vitousek. 2000. Regulation of soil phosphatase and chitinase activity by $\mathrm{N}$ and $\mathrm{P}$ availability. Biogeochemistry 49:175-190.

Reiners, W. A., A. F. Bouwman, W. F. J. Parsons, and M. Keller. 1994. Tropical rain forest conversion to pasture: changes in vegetation and soil properties. Ecological Applications 4:363-377.

Sanchez, P. A., D. E. Brady, J. H. Villachica, and J. J. Nicholaides. 1982. Amazon Basin soils: management for continuous crop production. Science 216:821-827.

Sanchez, P. A., J. H. Villachica, and D. E. Bandy. 1983. Soil fertility dynamics after clearing a tropical rain forest in Peru. Soil Science Society of America Journal 47:11711178.

Spaans, E. J. A., G. A. M. Baltissen, J. Bouma, R. Miedema, A. L. E. Lansu, D. Schoonderbeek, and W. G. Wielemaker. 1989. Changes in physical properties of young and old volcanic surface soils in Costa Rica after clearing of tropical rain forest. Hydrological Processes 3:383-392.

Speir, T. W., and J. C. Cowling. 1991. Phosphatase activities of plants and soils: relationship with plant productivity and soil $\mathrm{P}$ fertility indices. Biology and Fertility of Soils 12: 189-194.

SPSS. 2000. SPSS software for Macintosh. Version 10.0.7a. SPSS, Chicago, Illinois, USA.

Steel, R. G. D., and J. H. Torrie. 1960. Principles and procedures of statistics with special reference to the biological sciences. McGraw-Hill, New York, New York, USA.

Synergy Software. 2000. KaleidaGraph, Version 3.5. Synergy Software, Reading, Pennsylvania, USA.

Tabatabai, M. A., and J. M. Bremner. 1969. Use of p-nitrophenyl phosphatase for assay of soil phosphatase activity. Soil Biology and Biochemistry 1:301-307.
Tiessen, H., E. Cuevas, and P. Chacon. 1994. The role of soil organic matter in sustaining soil fertility. Nature 371:783785.

Tiessen, H., and J. O. Moir. 1993. Characterization of available P by sequential extraction. Pages $75-86$ in M. R. Carter, editor. Soil sampling and methods of analysis. Lewis Publishers, Boca Raton, Florida, USA.

Tiessen, H., I. H. Salcedo, and E. V. S. B. Sampaio. 1992. Nutrient and soil organic matter dynamics under shifting cultivation in semi-arid northeastern Brazil. Agriculture, Ecosystems and Environment 38:139-151.

Townsend, A. R., G. P. Asner, C. C. Cleveland, M. E. Lefer, and M. C. Bustamante. 2002. Unexpected changes in soil phosphorus dynamics following tropical deforestation to cattle pasture. Journal of Geophysical Research, 107 (D20), 8067, doi: 10.1029/2001 JD000650, 2002.

Trumbore, S. E., E. A. Davidson, P. B. De Camargo, D. C. Nepstad, and L. A. Martinelli. 1995. Below-ground cycling of carbon in forests and pastures of eastern Amazonia. Global Biogeochemical Cycles 9:512-528.

Uhl, C., and C. F. Jordan. 1984. Succession and nutrient dynamics following forest cutting and burning in Amazonia. Ecology 65:1476-1490.

Vance, E. D., P. C. Brookes, and D. S. Jenkinson. 1987. An extraction method for measuring soil microbial biomass $\mathrm{C}$. Soil Biology and Biochemistry 19:703-707.

Vazquez, F. J., M. J. Acea, and T. Carballas. 1993. Soil microbial populations after wildfire. FEMS Microbiology Ecology 13:93-104.

Veldkamp, E. 1994. Organic carbon turnover in three tropical soils under pasture after deforestation. Soil Science Society of America Journal 58:175-180.

Vitousek, P. M. 1984. Litterfall, nutrient cycling, and nutrient limitation in tropical forests. Ecology 65:285-298.

Vitousek, P. M., and J. R. L. Sanford. 1986. Nutrient cycling in moist tropical forest. Annual Review of Ecology and Systematics 17:137-167.

Werner, P. 1984. Changes in soil properties during tropical wet forest succession in Costa Rica. Biotropica 16:43-50.

Williams, J., and C. J. Chartres. 1991. Sustaining productive pastures in the tropics: managing the soil resource. Tropical Grasslands 25:73-84. 